\title{
Effects of Prior Heat Stress on the Growth and Phytochemical Contents Accumulation of Amaranthus hybridus (Linn.)
}

\section{Ezekiel Dare OLOWOLAJU ${ }^{1 *}$, Gideon Olarewaju OKUNLOLA ${ }^{2}$, Abiodun Mutairu ADEJUMO ${ }^{1}$, Adekunle Ajayi ADELUSI ${ }^{1}$}

\author{
${ }^{1}$ Obafemi Awolowo University, Faculty of Science, Department of Botany, Ile-Ife, \\ Nigeria; barenleezekiel@yahoo.com (*corresponding author) \\ ${ }^{2}$ Osun State University, Faculty of Science, Department of Biological Sciences, Osogbo, Nigeria
}

\begin{abstract}
The present study aimed at investigating the impact of abrupt heat stress on growth and phytochemical contents accumulation in Amaranthus hybridus. The treatments were as follows: control without heat treatment, seedlings subjected to heat at $45^{\circ} \mathrm{C}$ for two hours and seedlings subjected to heat at $45^{\circ} \mathrm{C}$ for four hours. After the stipulated time for each category, plants were removed from the Gallenkamp oven and were transplanted into other sets of thirty six pots (of $21 \mathrm{~cm}$ deep and 24 $\mathrm{cm}$ in diameter), as well as the control. The seedlings were kept in a screen house to minimise extraneous factors such as pests and rodents. They were watered daily with $200 \mathrm{~mL}$ of tap water in the morning and $200 \mathrm{~mL}$ of tap water in the evening until they were fully established. The phytochemical contents were determined at vegetative, flowering and fruiting stage using ethanolic extracts from the dried leaves of plant samples. From the results obtained, it was observed that leaf, shoot and root fresh and dry weights of the stressed plants were lower than the control plants. Exposure of the plants at different durations of heat treatment enhanced and inhibits the quantities of phytochemicals at different growth stages. From the present study it can be concluded that heat stress, on the basis of global warming in the future, will likely have overall negative effects on the growth of Amaranthus hybridus that will become more severe as the time of exposure increases and and might cause variation in the level of phytochemical constituents of Amaranthus hybridus at different growth stages.
\end{abstract}

Keywords: biochemical; early stage; growth; heat; phytochemicals; stress

\section{Introduction}

Physiological processes of plants are largely affected by alteration of surrounded environmental factors such as heat, light, rainfall, heavy metal, pathogenicity, nutrient deficiency, etc. Plants respond to these factors by acclimatization, avoidance and resistance. Most acclimatization strategies ranges from morpho-anatomical to physiological and biochemical strategies (Zhu, 2001). Plants select the sort of acclimatization by additive or synergistic effects of genetic constitution and resistance to be able to withstand and resist the effects of the environmental stress factors (Bray et al., 2000); avoidance involves the prevention or decreasing the impact of the stress on the plant, such as minimizing water loss and maximizing water uptake in case of drought (Chaves et al., 2003) or exclusion of salt ions (Munns et al., 2006).
Like other abiotic stresses, heat stress brings about a range of conditions that might positively or negatively influences the growth, development and function of an organism. Heat stress is a great modulator of growth and productivity (Zhang et al., 2000). Prevailing high temperature reduces crop yield and affect plant growth from germination up to maturity. The mechanism leading to the survival of a crop under heat stress entail changes in physiology and accumulation of osmolytes like proline, glycinebetaine, soluble sugars and proteins (Wahid and Close, 2007).

The stability of life processes in most plants is comparatively wide, whereas temperature ranges from several degrees above $0{ }^{\circ} \mathrm{C}$ to around $35^{\circ} \mathrm{C}$. The increase of temperature up to a certain level increases plant growth, photosynthesis, respiration and enzyme activity. After this temperature, such parameters tend to decline (Mirza et al., 2003). 
Amaranthus hybridus and other species of Amaranth have been used by various clans in African countries for a long time as indispensable constituents of human diets. Amaranthus hybridus has been shown to contain large amount of phytochemicals that have both health and industrial benefits (Rao and Newmark, 1998; He et al., 2003). These phytochemicals are alkaloids which function in the defence of plants against herbivores, glycosides and phenols which play an important role in the control of human pathogenic infections (Firn, 2010), flavonoids which are used as antioxidants, saponin which are extremely poisonous as they cause haemolysis of blood and can be used as soap, terpenes which are commonly found in essential oils or oleoresins (Firn, 2010). Others are essential oils, steroids and antraquinones are also noted. They are therefore mainly consumed for their nutritional and medicinal values with much consideration on their medicinal importance and their phytochemical contents which have been scarcely explored (Knekt et al., 1997).

Despite the vast use of this vegetable, there is paucity of information on the effect of some environmental factors which can disrupt the growth and phytochemical constituents of this species. The present work therefore aimed at documenting the effect of heat stress on the growth and phytochemical contents of $A$. hybridus in a bid to provide information on the limiting factor which can affect the growth and phytochemical constituents.

\section{Materials and Methods}

\section{Collection of seeds}

Seeds of Amaranthus hybridus were utilised for the present experiment. The seeds were obtained from Nigeria Horticulture Research Institute (NIHORT), Ibadan, Nigeria.

\section{Raising of seedlings}

The experiment was carried out under a screenhouse to minimise extraneous factors such as insects, pests and other materials that may alter the course of this experiment. Germination was carried out in a nursey. Three small bowls (each of $12 \mathrm{~cm}$ in diameter and $5 \mathrm{~cm}$ high) were used to germinate the seeds. Holes about $2 \mathrm{~mm}$ were bored at the bottom to allow for proper drainage of excess water. The bowls were labelled as A, B and C. After three weeks of sowing, two of the three pots (A and $\mathrm{B}$ ) were put inside a Gallenkamp oven for heat treatment. The two stressed categories were subjected to the same temperature (at 45 $\left.{ }^{\circ} \mathrm{C}\right)$, but had different durations; pot A was left in the oven for 2 hours and pot $B$ for 4 hours. After the stipulated time for each category, they were both removed and along with the control samples were transplanted into another 36 sets of pots (of $21 \mathrm{~cm}$ in deep and $24 \mathrm{~cm}$ in diameter) with bored holes at the bottom of each pot to allow proper drainage. The seedlings were divided into three categories containing 12 pots for the stressed plants at $45^{\circ} \mathrm{C}$ for 2 hours, 12 pots for 4 hours at $45^{\circ} \mathrm{C}$ and the last 12 pots for the control. The seeds were sown at the rate of three seeds per pots.

\section{Measurements of some morphological parameters}

Measurements of some morphological parameters were taken: leaf fresh and dry weights, shoot fresh and dry weights and root fresh and dry weights. For fresh weights determination, plants were carefully uprooted and the sand particles that were attached to the roots were washed off with water and then mopped to drain the water. The fresh plants were taken on a weighing balance after which they were dried on a Gallenkamp oven at $80^{\circ} \mathrm{C}$ for 72 hours. This procedure was repeated at seven day intervals.

\section{Processing of plant samples for phytochemical screening}

The leaves of Amaranthus hybridus were harvested, properly washed, oven dried at $40{ }^{\circ} \mathrm{C}$ and grinded to a powdered form with mortar and pestle. This process was done separately for the three growth stages and placed in separate, labeled glass bottles.

\section{Preparation of ethanolic extract of plant samples}

The aqueous extract of each plant sample at different growth stages was prepared by soaking $5 \mathrm{~g}$ of powdered samples in $200 \mathrm{~mL}$ of ethanol for two weeks. The extract was then filtered using Whatman's No 1 filter paper.

\section{Phytochemical analysis}

Qualitative analysis was carried out to ascertain the presence of the different phytochemicals as described by Edeoga et al. (2005).

\section{Test for tannins}

Tannin was determined by the Folin-Denis colorimetric method. About $0.5 \mathrm{~g}$ of the extracts of each plant were boiled in $20 \mathrm{~mL}$ of water in a test tube and then filtered. A few drops of $0.1 \%$ ferric chloride were added. A brownish green or a blue-black coloration indicated the presence of tannins.

\section{Test for saponins}

Two mg of the extracts of each plant were boiled together with $20 \mathrm{~mL}$ of distilled water in a water bath, vigorously shaken and noted for froth. The appearance and persistence of frothing before and after warming indicated the presence of saponins.

\section{Test for flavonoids}

Five $\mathrm{mL}$ of dilute ammonia solution were added to the ethanolic extract of each plant sample in a test tube, followed by addition of concentrated $\mathrm{H}_{2} \mathrm{SO}_{4}$. A yellow coloration was observed and disappeared on standing. This indicated the presence of flavonoids.

\section{Test for phenol}

A sample of $500 \mathrm{mg}$ of the extract was dissolved in $5 \mathrm{~mL}$ of distilled water. To this, few drops of neutral ferric chloride solution was added. A dark green color indicated the presence of phenolic compounds.

\section{Test for alkaloids}

Five $\mathrm{mL}$ solution of the extract and $2 \mathrm{~mL}$ of dilute hydrochloric acid were taken in a test tube. Then $1 \mathrm{~mL}$ of Dragendroffs reagent was added to this acidic medium. Orange or red precipitate was formed and that indicated the presence of alkaloids. 
242

\section{Test for steroids}

Two $\mathrm{mL}$ of acetic anhydride were added to $0.5 \mathrm{~g}$ ethanolic extract of each sample with $2 \mathrm{~mL} \mathrm{H}_{2} \mathrm{SO}_{4}$. The change of color from violet to blue or green in some samples indicated the presence of steroids.

\section{Test for reducing sugars}

About $5 \mathrm{~g}$ each of the dried samples in a test tube, equal amount of Fehling's solution A and B were added. The mixture was boiled over a burner. Observation of colour was made. A colour change from deep blue to brick red indicated the presence of reducing sugar.

\section{Test for phlobatannins}

When the leaf extract was boiled with $2 \mathrm{ml}$ of $1 \%$ hydrochloric acid, formation of red precipitate indicated the presence of phlobatanin.

\section{Statistical analysis}

The statistical analysis was performed using Statistical Analytical Software (SAS) version 9.2. A one way analysis of variance (ANOVA) was carried out to investigate the impact of heat stress on the growth and phytochemical contents of Amaranthus hybridus. Post hoc setting testing was carried out using Duncan Multiple Range test to separate the significance means at 0.05 confidence limit (alpha level).

\section{Results}

Effect of prior heat stress on the growth of Amaranthus bybridus

The leaf fresh weight and leaf dry weights of the stressed plants were lower to the control plants at each course of the experimental period. The plant exposed to heat for four hours had the lowest leaf fresh weight and dry weight compared with those exposed for two hours and the control, while the control plants recorded the highest value $\left(\right.$ at $\left.45^{\circ} \mathrm{C}\right)$ (Table 1). There was a significant effect of heat stress on this attributes to the control plants.

The shoot fresh weights and dry weight tended to decline with heat stress as the duration of exposure increased. The plants stressed for four hours recorded the lowest shoot fresh weights and dry weight, followed by those exposed for two hours, while the control plants had the highest shoot fresh weights and dry weight throughout the entire period of the experiment (Table 2).

Like total leaf fresh weight and leaf dry weights, shoot fresh weights and dry weight it was discovered from the results obtained that the root fresh weights and root dry weights of those plants exposed to heat for four hours were the lowest and that of the control were the highest throughout the experimental period. The results showed that there was a significant difference in the leaf fresh weight and leaf dry weights of the stressed plants to that of the control plants (Table 3).

\section{Effect of heat stress on the phytochemical content of} Amaranthus hybridus

The results obtained from the qualitative analysis of $A$. bybridus showed that alkaloids, tannins, saponins and flavonoids were all present in the control, plants stressed for 2 hours and plants stressed for 4 hours. Reducing sugars, terpenoids, phlobatannins were absent in these treatments (Table 4).

The results obtained from the quantitative analysis showed that saponins was highest in the plants stressed for

Table 1. Effect of prior heat stress at the seedling stage, on the leaf fresh and dry weights of Amaranthus hybridus

\begin{tabular}{|c|c|c|c|c|c|c|c|c|c|}
\hline & \multirow[b]{2}{*}{ Treatments } & \multicolumn{8}{|c|}{ Weeks after sowing } \\
\hline & & 1 & 2 & 3 & 4 & 5 & 6 & 7 & 8 \\
\hline \multirow[t]{3}{*}{$\begin{array}{l}\text { Leaf fresh } \\
\text { weights }\end{array}$} & Control & 2. $01 \mathrm{~b}$ & $2.27 \mathrm{~b}$ & $4.10 \mathrm{~b}$ & $5.22 \mathrm{c}$ & $8.02 b$ & $8.36 b$ & $9.46 \mathrm{~b}$ & $10.32 \mathrm{~b}$ \\
\hline & 2 Hours & $2.10 \mathrm{a}$ & $2.59 \mathrm{a}$ & $4.45 \mathrm{a}$ & $8.14 \mathrm{a}$ & $9.33 \mathrm{a}$ & $9.57 \mathrm{a}$ & $10.37 \mathrm{a}$ & $11.45 \mathrm{a}$ \\
\hline & 4 Hours & $1.67 \mathrm{c}$ & $1.79 \mathrm{c}$ & $3.66 \mathrm{a}$ & $5.36 b$ & $7.47 \mathrm{c}$ & $7.58 \mathrm{c}$ & $8.69 \mathrm{c}$ & $9.01 \mathrm{c}$ \\
\hline \multirow[t]{3}{*}{$\begin{array}{l}\text { Leaf dry } \\
\text { weights }\end{array}$} & Control & $0.29 \mathrm{a}$ & $0.40 \mathrm{a}$ & $0.66 \mathrm{a}$ & $0.68 \mathrm{a}$ & $0.82 \mathrm{a}$ & $0.98 \mathrm{a}$ & $1.16 \mathrm{a}$ & $2.49 \mathrm{a}$ \\
\hline & 2 Hours & $0.24 b$ & $0.38 b$ & $0.59 \mathrm{~b}$ & $0.63 b$ & $0.81 b$ & $0.96 b$ & $1.16 \mathrm{a}$ & $2.41 b$ \\
\hline & 4 Hours & $0.24 b$ & $0.32 \mathrm{c}$ & $0.42 \mathrm{c}$ & $0.57 \mathrm{c}$ & $0.54 \mathrm{c}$ & $0.69 \mathrm{c}$ & $0.94 b$ & $2.36 \mathrm{c}$ \\
\hline
\end{tabular}

Means with the same superscript along the same column are not significantly different at $\mathrm{P}>0$.

Table 2. Effect of prior heat stress at the seedling stage, on the shoot fresh and dry weights of Amaranthus bybridus

\begin{tabular}{|c|c|c|c|c|c|c|c|c|c|}
\hline & & \multicolumn{8}{|c|}{ Weeks after sowing } \\
\hline & Treatments & 1 & 2 & 3 & 4 & 5 & 6 & 7 & 8 \\
\hline $\begin{array}{c}\text { Shoot fresh } \\
\text { weights }\end{array}$ & Control & $3.05 b$ & $4.98 \mathrm{a}$ & $6.68 b$ & $8.01 \mathrm{~b}$ & $9.24 \mathrm{a}$ & $10.53 a$ & $11.24 \mathrm{~b}$ & $13.78 \mathrm{a}$ \\
\hline & 2 Hours & $3.96 \mathrm{a}$ & $4.46 \mathrm{a}$ & $7.16 \mathrm{a}$ & $9.05 \mathrm{a}$ & $7.52 b$ & $10.15 b$ & $11.78 \mathrm{a}$ & $13.71 b$ \\
\hline & 4 Hours & $2.42 \mathrm{c}$ & $2.88 \mathrm{c}$ & $6.447 \mathrm{c}$ & $7.31 \mathrm{c}$ & $7.58 \mathrm{c}$ & $9.01 \mathrm{c}$ & $10.85 \mathrm{c}$ & $12.65 c$ \\
\hline $\begin{array}{c}\text { Shoot dry } \\
\text { weights }\end{array}$ & Control & $0.33 \mathrm{a}$ & $0.53 \mathrm{a}$ & $0.92 \mathrm{a}$ & $1.12 \mathrm{a}$ & $1.60 \mathrm{~b}$ & $1.96 \mathrm{a}$ & $2.64 a$ & $3.14 \mathrm{a}$ \\
\hline & 2 Hours & $0.31 \mathrm{a}$ & $0.49 \mathrm{~b}$ & $0.77 b$ & $1.10 \mathrm{~b}$ & $1.71 \mathrm{a}$ & $1.96 \mathrm{a}$ & $2.53 b$ & $3.10 \mathrm{~b}$ \\
\hline & 4 Hours & $0.22 \mathrm{c}$ & $0.39 \mathrm{c}$ & $0.52 \mathrm{c}$ & $0.94 \mathrm{c}$ & $1.20 \mathrm{c}$ & $1.67 \mathrm{~b}$ & $2.18 \mathrm{c}$ & $3.00 \mathrm{c}$ \\
\hline
\end{tabular}


Table 3. Effect of prior heat stress at the seedling stage, on the root fresh and dry weights of Amaranthus hybridus

\begin{tabular}{|c|c|c|c|c|c|c|c|c|c|}
\hline & \multirow[b]{2}{*}{ Treatments } & \multicolumn{8}{|c|}{ Weeks after sowing } \\
\hline & & 1 & 2 & 3 & 4 & 5 & 6 & 7 & 8 \\
\hline \multirow[t]{3}{*}{$\begin{array}{l}\text { Root fresh } \\
\text { weights }\end{array}$} & Control & $0.44 a$ & $0.73 \mathrm{a}$ & $1.28 \mathrm{a}$ & $1.99 \mathrm{a}$ & $2.00 \mathrm{~b}$ & $2.86 \mathrm{~b}$ & $2.98 \mathrm{a}$ & $3.78 \mathrm{a}$ \\
\hline & 2 Hours & $0.31 b$ & $0.50 \mathrm{~b}$ & $1.25 \mathrm{~b}$ & $1.89 \mathrm{~b}$ & $2.08 \mathrm{a}$ & $2.87 \mathrm{a}$ & $2.71 \mathrm{~b}$ & $3.77 \mathrm{~b}$ \\
\hline & 4 Hours & $0.26 \mathrm{c}$ & $0.34 \mathrm{c}$ & $1.03 \mathrm{c}$ & $1.78 \mathrm{c}$ & $1.90 \mathrm{c}$ & $2.67 \mathrm{c}$ & $2.62 \mathrm{c}$ & $3.56 \mathrm{c}$ \\
\hline \multirow[t]{3}{*}{$\begin{array}{l}\text { Root dry } \\
\text { weights }\end{array}$} & Control & $0.04 a$ & $0.06 \mathrm{~b}$ & $0.07 \mathrm{a}$ & $0 / 17 \mathrm{a}$ & $0.19 \mathrm{a}$ & $0.21 \mathrm{a}$ & $0.28 \mathrm{a}$ & $0.44 \mathrm{a}$ \\
\hline & 2 Hours & $0.03 \mathrm{~b}$ & $0.08 \mathrm{a}$ & $0.07 \mathrm{a}$ & $0.12 b$ & $0.18 b$ & $0.20 \mathrm{~b}$ & $0.28 \mathrm{a}$ & $0.44 \mathrm{a}$ \\
\hline & 4 Hours & $0.01 \mathrm{c}$ & $0.02 \mathrm{c}$ & $0.05 b$ & $0.10 \mathrm{c}$ & $0.14 \mathrm{c}$ & $0.18 \mathrm{c}$ & $0.27 b$ & $0.39 \mathrm{c}$ \\
\hline
\end{tabular}

Means with the same superscript along the same column are not significantly different at $\mathrm{P}>0.05$

Table 4. Effect of heat stress on the presence and absence phytochemical content of Amaranthus hybridus

\begin{tabular}{|c|c|c|c|}
\hline \multicolumn{4}{|c|}{ Treatments } \\
\hline Phytochemicals & Control & 2 Hours stress & 4 Hours stress \\
\hline Alkaloids & + & + & + \\
\hline Reducing Sugars & - & - & - \\
\hline Terpenoids & - & - & - \\
\hline Tannins & + & + & + \\
\hline Saponins & + & + & + \\
\hline Flavonoids & + & + & + \\
\hline Phenolics & - & - & - \\
\hline Phlobatanins & - & - & - \\
\hline
\end{tabular}

Table 5. Effect of heat stress on the phytochemical content of Amaranthus bybridus

\begin{tabular}{|c|c|c|c|c|}
\hline \multicolumn{5}{|c|}{ Treatments } \\
\hline & Phytochemicals & Control (\%) & 2 Hours stress $(\%)$ & 4 Hours stress (\%) \\
\hline \multirow[t]{4}{*}{ Vegetative stage } & Saponins & $0.234 \mathrm{~b}$ & $0.257 \mathrm{a}$ & $0.193 \mathrm{c}$ \\
\hline & Tannins & $0.998 \mathrm{a}$ & $0.965 \mathrm{~b}$ & $0.908 \mathrm{c}$ \\
\hline & Flavonoids & $0.269 \mathrm{c}$ & $0.275 b$ & $0.277 \mathrm{a}$ \\
\hline & Alkaloids & $0.164 \mathrm{c}$ & $0.204 a$ & $0.173 b$ \\
\hline \multirow[t]{4}{*}{ Flowering stage } & Saponins & $0.327 \mathrm{a}$ & $0.305 b$ & $0.296 \mathrm{c}$ \\
\hline & Tannins & $0.879 \mathrm{~b}$ & $0.849 \mathrm{c}$ & $0.967 \mathrm{a}$ \\
\hline & Flavonoids & $0.153 \mathrm{c}$ & $0.205 b$ & $0.239 \mathrm{a}$ \\
\hline & Alkaloids & $0.231 b$ & $0.212 \mathrm{c}$ & $0.233 \mathrm{a}$ \\
\hline \multirow[t]{4}{*}{ Fruiting stage } & Saponins & $0.348 b$ & $0.394 \mathrm{a}$ & $0.305 c$ \\
\hline & Tannins & $1.139 \mathrm{a}$ & $1.057 \mathrm{~b}$ & $0.882 \mathrm{c}$ \\
\hline & Flavonoids & $0.078 \mathrm{a}$ & $0.072 b$ & $0.057 \mathrm{c}$ \\
\hline & Alkaloids & $0.348 \mathrm{c}$ & $0.387 \mathrm{a}$ & $0.369 \mathrm{~b}$ \\
\hline
\end{tabular}

Means with the same superscript along the same row are not significantly different at $\mathrm{P}>0.05$

2 hours and was lowest in the plants stressed for 4 hours at vegetative and fruiting stage. At flowering stage, it was highest in the control and was lowest in the plants stressed for 4 hours (Table 5 ).

At vegetative and fruiting stage, tannins accumulation was highest in the control plants and was lowest in the plants stressed for 4 hours. At flowering stage, tannins accumulation was highest in the plants stressed for 4 hours and was lowest in the plants stressed for 2 hours (Table 5).
At vegetative and flowering stage, flavonoids were highest in the plants stressed for 4 hours and lowest in the control. At fruiting it was highest in the control plants and was lowest in the plants stressed for 4 hours (Table 5).

Alkaloids were highest in the plants stressed for 2 hours and were lowest in the control at vegetative and fruiting stage. At flowering stage, it was highest in the stressed for 4 hours and was lowest in the plants stressed for two hours (Table 5). 
244

It was observed that there were significant differences in the level of phytochemical contents of Amaranthus hybridus among the treatments $(\mathrm{P}>0.05)$.

\section{Discussion}

With increased temperature due to global warming, plants are likely to experience increasingly frequent hotter and longer episodes of abrupt heat stress (i.e. heat waves) in the future and this will negatively impact plant function (Giri, 2013). The results from the current study showed that exposure of Amaranthus hybridus at different duration of heat negatively affects their growth, but the effect on the phytochemical constituents at different stages of growth enhanced the quantity of some phytochemicals and inhibit the quantity of others. As in other previous studies (Heckathorn et al., 2013), among roots and shoots subjected to the same high temperatures, roots were more sensitive to heat stress than shoots. In the hereby study, both root and shoot growth as expressed by their fresh and dry weights decreased at high duration of heat stress at $45^{\circ} \mathrm{C}$. This might have contributed to the decrease observed in the leaf fresh and dry weights, consistent with results of a study on abrupt heat stress in a heat-tolerant grass (Mainali, 2007). The probable reason for lower shoot, root and leaf fresh and dry weight in the heat treatments compared to the control is that roots sustained direct damage from this temperature at higher duration, as indicated by heat-related increases in root electrolyte leakage (an indication of membrane damage), as observed in other studies (Liu and Huang, 2000, 2002).

The estimated relative activities of the phytochemicals during heat stress at different stages of growth were variable with the control plants. The phytochemical accumulation detected in this species showed dissimilar responses to heat stress as some of the phytochemicals were enhanced by heat, some were inhibited at vegetative, flowering and fruiting stage. This showed that heat stress at $45^{\circ} \mathrm{C}$ for two hours and four hours exposure did not decrease nor increase the relative activities of phytochemical constituents of Amaranthus hybridus as obtained at different growth stages though there were variations in the quantities of these phytochemicals at different stages of growth.

\section{Conclusions}

The results from the present study indicated that heat stress at different durations impaired growth parameters of Amaranthus bybridus. It can be inferred that increase in the duration of exposure to heat negatively affect growth parameters such as leaf fresh and dry weights, shoot fresh and dry weights, as well as root fresh and dry weights. Also, heat stress increases the accumulation of some phytochemical components, while it causes negative effects on some phytochemical attributes of Amaranthus hybridus at different stages of growth. It can therefore be concluded that heat stress with global warming in the future will likely have overall negative effects on the growth of Amaranthus bybridus and might cause variation in the level of phytochemical constituents of Amaranthus hybridus at different growth stages.

\section{References}

Bray EA, Bailey-Serres J, Weretilnyk E (2000). Responses to abiotic stresses. In: Gruissem W, Buchannan B, Jones R (Eds). Biochemistry and Molecular Biology of Plants. American Society of Plant Physiologists, Rockville, MD pp 1158-1249.

Chaves MM, Maroco JP, Pereira JS (2003). Understanding plant responses to drought from gene to the whole plant. Functional Plant Biology 30(3):239-289.

Edeoga HO, Okwu DE, Mbaebie BO (2005). Phytochemical constituents of some Nigerian medicinal plants. African Journal of Biotechnology $4(7): 685-688$.

Firn R(2010). Nature chemicals. Oxford University Press pp 7475.

Giri A (2013). Effect of acute heat stress on nutrient uptake by plant roots. Theses and Dissertations. The University of Toledo, pp 32.

He HP, Corke H, Cai JG (2003). Supercritical carbon dioxide extraction of oil and squalene from Amaranthus grain. Journal of Agricultural and Food Chemistry 51(27):7921-7925.

Heckathorn SA, Giri A, Mishra S, Bista D (2013). Heat stress and roots. In N.T.A.S.Gill (Ed), Climate Change. Germany: Wiley-VCH.

Knekt P, Jarvinen R, Seanen M, Heliovaara L, Aromaa A (1997). Dietary flavonoids and the risk of lung cancer and other malignant neoplasms. American Journal of Epidemiology 146:223-230.

Liu X, Huang B (2000). Heat stress injury in relation to membrane lipid peroxidation in creepingbentgrass. CropScience 40(2):503-510.

Liu X, Huang B (2002). Cytokinin effects on creeping bentgrass response to heat stress. Crop Science 42(2):466-472.

Mainali KP (2007). Impact of heat waves on plant-soil links in tall-grass prairie. The University of Toledo.

Mirza H, Kamrun F, Masavuki F (2003). Extreme temperature responses, oxidative and antioxidant defense in plants. In: Abiotic stress - Plant responses and applications in agriculture. InTech.

Muuns R, James RA, Lauchli A (2006). Approaches to increasing the heat tolerance of wheat and other cereals. Journal of Experimental Botany 57:645-663.

Rao CV, Newmark HL (1998). Chemo-revenive effect of squalene on colon cancer. Carcinogenesis. Journal of Medicinal Plants 19:287-290.

Wahid A, Close TJ (2007). Expression of dehydrin under heat stress and their relationship with water relations of sugarcane leaves. Biologia Plantarum 51:104-109.

Zhang W, Wang SY (2000). Antioxidant activity and phenolic compounds in selected herbs. Journal of Agriculture and Food Chemistry 49(11):5165-5170.

Zhu JK (2001). Genetic analysis of plant salt tolerance using Arabidopsis. Plant Physiology 124: 941-948. 